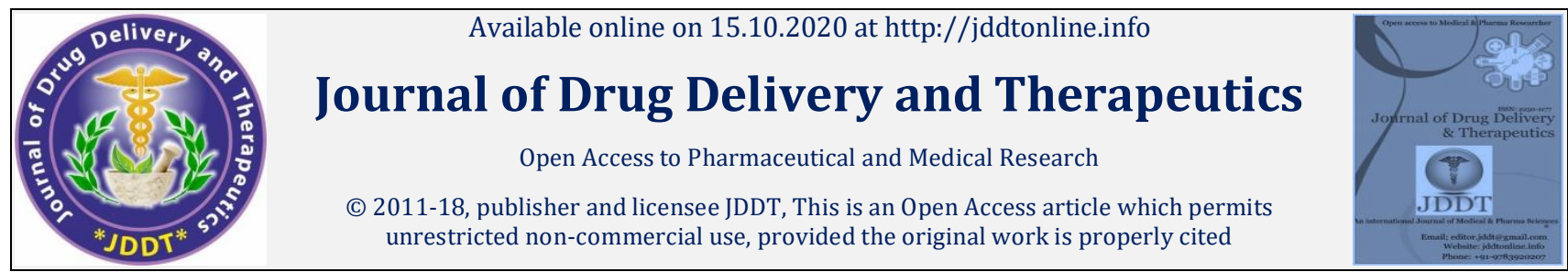

Open 1 Access

Research Article

\title{
Method Development and Validation for Multicomponent Analysis of Rosuvastatin Calcium and Losartan Potassium in Bulk Drug by RP-HPLC
}

\author{
Pramod Kumar*, Amar Deep Ankalgi, Pooja Kaushal, Mahendra Singh Ashawat \\ Department of Pharmaceutical Analysis \& Quality Assurance, Laureate Institute of Pharmacy Kathog Jawalaji, H.P., India
}

\begin{abstract}
A simple, sensitive and specific liquid chromatographic method was developed for the simultaneous estimation of Rosuvastatin calcium and Losartan potassium in bulk form. Chromatographic conditions included the Column C-18 (Shim-pack) 250 x $4.6 \mathrm{~mm}$, particle size $5 \mu \mathrm{m}$, mobile phase acetonitrile, methanol and water $\mathrm{pH} 3$ (orthophosphoric acid) in the ratio 20:25:55 recorded at $233 \mathrm{~nm}$. The retention time were found to be 3.55 and $4.64 \mathrm{~min}$ and average percentage recovery $99.42 \%$ and $99.63 \%$ for Rosuvastatin calcium and Losartan potassium respectively. The proposed method was found to comply with ICH guidelines.
\end{abstract}

Keyword: Rosuvastatin calcium, Losartan potassium, RP-HPLC, accuracy and linearity.

Article Info: Received 07 Aug 2020; $\quad$ Review Completed 14 Sep 2020; $\quad$ Accepted 22 Sep 2020; $\quad$ Available online 15 Oct 2020

Cite this article as:

Kumar P, Ankalgi AD, Kaushal P, Ashawat MS, Method Development and Validation for Multicomponent Analysis of Rosuvastatin Calcium and Losartan Potassium in Bulk Drug by RP-HPLC, Journal of Drug Delivery and Therapeutics. 2020; 10(5-s):76-84 http://dx.doi.org/10.22270/jddt.v10i5-s.4341

*Address for Correspondence:

Pramod Kumar, Department of Pharmaceutical Analysis \&Quality Assurance, Laureate Institute of Pharmacy Kathog

Jawalaji, H.P., India

\section{INTRODUCTION1-10:}

calcium (Fig 1) is a lipid-lowering drug that belongs to the statin class of medications. Used to lower the risk of cardiovascular disease and manage abnormal lipid levels. Rosuvastatin is a statin derivative and a competitive inhibitor of the enzyme HMG-CoA (3-hydroxy-3methylglutaryl coenzyme A) reductase, which catalyzes the conversion of HMG-CoA to mevalonate which is early ratelimiting step in cholesterol biosynthesis.<smiles>CCc1nc(N(C)S(C)(=O)=O)nc(-c2ccc(F)cc2)c1/C=C/C(O)C[C@@H](O)CC(=O)[O-]</smiles>

Figure 1: Structure of Rosuvastatin calcium
Losartan (Fig 2) is an angiotensin II receptor blocker (ARB) used to treat hypertension. Losartan reversibly and competitively prevents angiotensin II binding to the $\mathrm{AT}_{1}$ receptor in tissues like vascular smooth muscle and the adrenal gland. Losartan and its active metabolite bind the $\mathrm{AT}_{1}$ receptor with 1000 times more affinity than they bind to the $\mathrm{AT}_{2}$ receptor.<smiles>[Z7]n1nnnc1-c1ccccc1-c1ccc(Cn2c(CCCC)nc(Cl)c2CO)cc1</smiles>

Figure 2: Structure of Losartan potassium

Literature review revealed only few efficient methods were available for quantitative estimation of the both the drugs. Hence, an attempt has been made to develop cost effective, 
simple and precise RP-HPLC method to estimate both drugs in bulk drug. Quantitative analysis plays an important role in the development of new drugs and their commercial production as formulations. Pharmaceutical industries rely upon quantitative chemical analysis to ensure that the raw material used and the final products obtained meet the required specifications. So here an attempt has been made to develop simple, rapid and economic method for simultaneous estimation of Rosuvastatin calcium and Losartan potassium in bulk drug and formulation by using High Performance Liquid Chromatography.

\section{EXPERIMENTAL WORK11-16:}

\subsection{Chemicals and reagents}

HPLC grade Acetonitrile, o-phosphoric acid, HPLC grade methanol, water, $\mathrm{pH}$ buffer capsule 4.0, 7.0, 9.2, phosphate buffer, THF, Rosuvastatin calcium and Losartan potassium.

2.2 Instrumentation: High Performance Liquid Chromatography (Shimadzu), manual sampler, software Win chrome and detector (UV-visible), Column C-18 (Shim-pack) $250 \times 4.6 \mathrm{~mm}$, particle size $5 \mu \mathrm{m}$.

\subsection{Preparation of stock solutions, working solutions and calibration standards}

Standard Rosuvastatin calcium $100 \mathrm{mg}$ was weighed and transferred to a $100 \mathrm{ml}$ volumetric flask and dissolved in methanol. The flask was shaken and sonicate for 30 minute at $45^{\circ} \mathrm{C}$ and volume was made up to the mark with solvent. 10 $\mathrm{ml}$ of solution was pipetted out from this and transferred to $100 \mathrm{ml}$ volumetric flask and the volume was made up to 100 $\mathrm{ml}$ with methanol. The conc. of prepared stock solution was $100 \mu \mathrm{g} / \mathrm{ml}$.

Standard Losartan potassium $100 \mathrm{mg}$ was weighed and transferred to a $100 \mathrm{ml}$ volumetric flask and dissolved in methanol. The flask was shaken and sonicate for 30 minute at $45^{\circ} \mathrm{C}$ and volume was made up to the mark with solvent 10 $\mathrm{ml}$ of solution was pipetted out from this and transferred to $100 \mathrm{ml}$ volumetric flask and the volume was made up to 100 $\mathrm{ml}$ with methanol. The conc. of prepared stock solution was $100 \mu \mathrm{g} / \mathrm{ml}$.

\subsection{Selection of wavelength}

The sensitivity of HPLC method that uses UV detection depends upon proper selection of detection wavelength. An ideal wavelength is the one that gives good response for the drugs that are to be detected. For the selection of wavelength $10 \mu \mathrm{g} / \mathrm{mL}$ concentration of Rosuvastatin calcium and 10 $\mu \mathrm{g} / \mathrm{mL}$ concentration of Losartan potassium was prepared in methanol and overlain spectra were obtained on UV spectrophotometer. The result of trials showed at $233 \mathrm{~nm}$ wavelength was most suitable for the analysis.

\subsection{Selection of chromatographic condition}

Chromatographic separation was achieved at ambient temperature on a reversed phase isocratic high performance liquid chromatography using a mobile phase consisting of methanol, acetonitrile and water by adjusting its $\mathrm{pH} 3$ with orthophosphoric acid. The mobile phase was pumped at a rate of $1.0 \mathrm{~mL} / \mathrm{min}$. The detector wavelength was set at 235 $\mathrm{nm}$ and run time was 10 minutes.

To optimize the chromatographic conditions, the effect of chromatographic variables such as mobile phase $\mathrm{pH}$ and flow rate were studied. The resulting chromatograms were recorded and the chromatographic responses were measured.

\section{RESULT AND DISCUSSION}

3.1 Optimized Method development ${ }^{17-19}$. The selection of the composition of mobile phase were studied and optimized. Separation was found to be satisfactory with acetonitrile, methanol and water $\mathrm{pH} 3$ (orthophosphoric acid) in the ratio of 20:25:55 \%, v/v. UV detection was carried out at $233 \mathrm{~nm}$ where both the drugs exhibit maximum absorption. Isocratic mode was chosen as the retention for both the drugs were less than 6 min at a flow rate of $1 \mathrm{ml} / \mathrm{min}$. Retention time for Rosuvastatin calcium and Losartan potassium with retention time of 3.55 and 4.64 min. The chromatogram of optimized trial is shown in Fig 3.

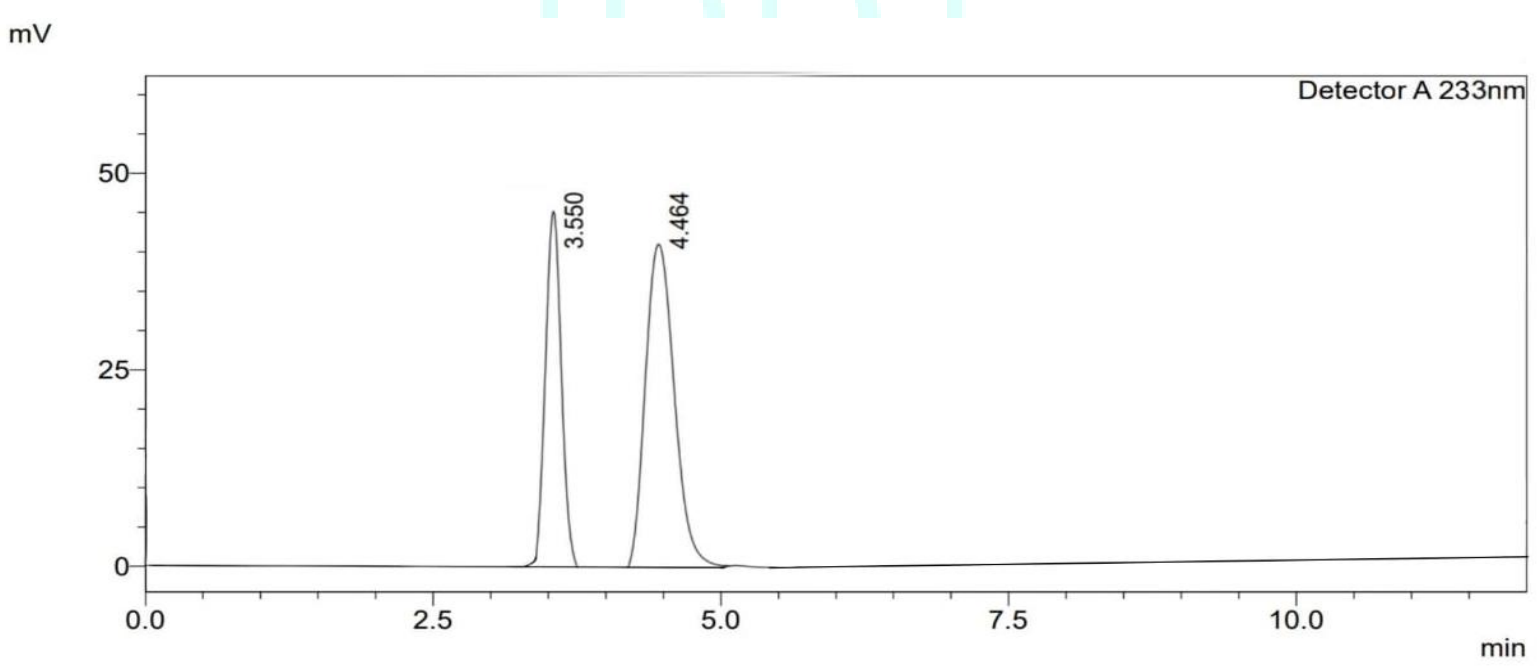

Figure 3: Optimized chromatogram of standard drug containing $10 \mu \mathrm{g} / \mathrm{ml}$ Rosuvastatin calcium and $10 \mu \mathrm{g} / \mathrm{ml} \mathrm{Losartan}$ potassium at wavelength $233 \mathrm{~nm}$ 


\subsection{Validation of the developed method}

\subsubsection{Linearity curve for the Rosuvastatin calcium ${ }^{20-22}$ :}

From the standard stock solution of Rosuvastatin calcium $(100 \mu \mathrm{g} / \mathrm{mL}) 2,4,6,8$ and 10 were pipetted out and transferred to separate $10 \mathrm{ml}$ of volumetric flasks and the volume was made up to $10 \mathrm{ml}$ with the help of mobile phase.
These concentrations were of $20,40,60,80$ and $100 \mu \mathrm{g} / \mathrm{ml}$ respectively. The injection was given at time interval of 10 minutes with run time of 10 minutes. The linearity was obtained in selected conc. ranges. Linearity of Rosuvastatin calcium is shown in Table 1 and calibration plot in Fig 4.

Table 1: Linearity curve of Rosuvastatin calcium at wavelength $233 \mathbf{n m}$.

\begin{tabular}{|c|c|c|}
\hline Sr. No & $\begin{array}{c}\text { Conc. } \\
(\boldsymbol{\mu g} / \mathbf{m L})\end{array}$ & Area $(\boldsymbol{\mu}$ volt sec. $)$ \\
\hline 1 & 20 & 1548754 \\
\hline 2 & 40 & 3198757 \\
\hline 3 & 60 & 4658794 \\
\hline 4 & 80 & 6352489 \\
\hline 5 & 100 & 8125481 \\
\hline
\end{tabular}

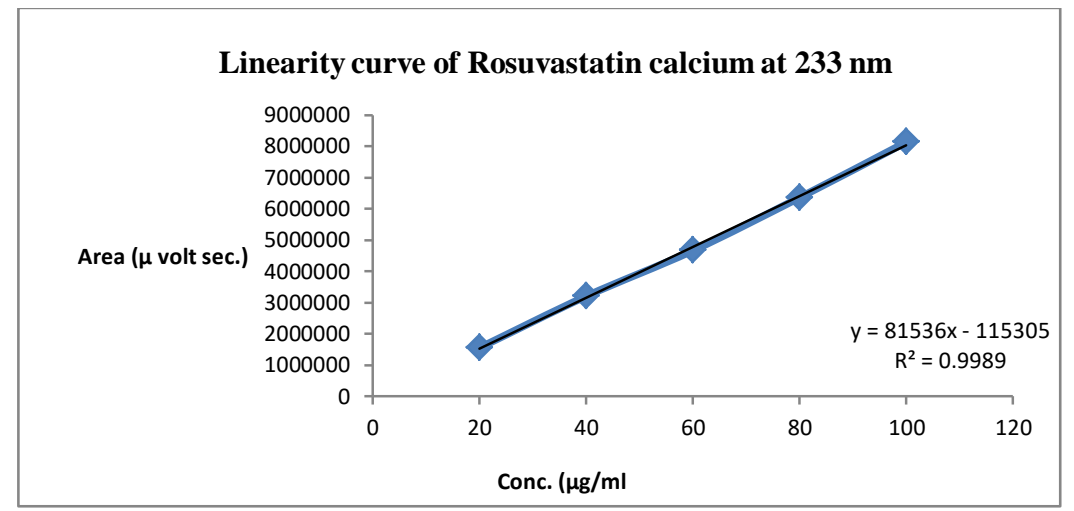

Figure 4: Calibration plot of Rosuvastatin calcium at $233 \mathrm{~nm}$

\subsubsection{Linearity curve for the Losartan Potassium:}

For Losartan potassium from standard stock solution (100 $\mu \mathrm{g} / \mathrm{mL}) 1.5,3,4.5,6$ and $7.5 \mathrm{ml}$ were pipetted out and transferred to separate $10 \mathrm{ml}$ of volumetric flasks and the volume was made up to mark respectively with solvent. These concentrations were of $15,30,45,60$ and $75 \mu \mathrm{g} / \mathrm{ml}$ respectively. The linearity was obtained in selected conc. ranges. Linearity of Rosuvastatin calcium is shown in Table 2 and calibration plot in Fig 5.

Table 2: linearity curve of Losartan Potassium at wavelength $233 \mathbf{~ n m}$.

\begin{tabular}{|c|c|c|}
\hline Sr. No & $\begin{array}{c}\text { Conc. } \\
(\boldsymbol{\mu} \mathbf{g} / \mathbf{m L})\end{array}$ & Area $(\boldsymbol{\mu}$ volt sec. $)$ \\
\hline 1 & 15 & 1310158 \\
\hline 2 & 30 & 2548455 \\
\hline 3 & 45 & 4015878 \\
\hline 4 & 60 & 5287945 \\
\hline 5 & 75 & 6475485 \\
\hline
\end{tabular}

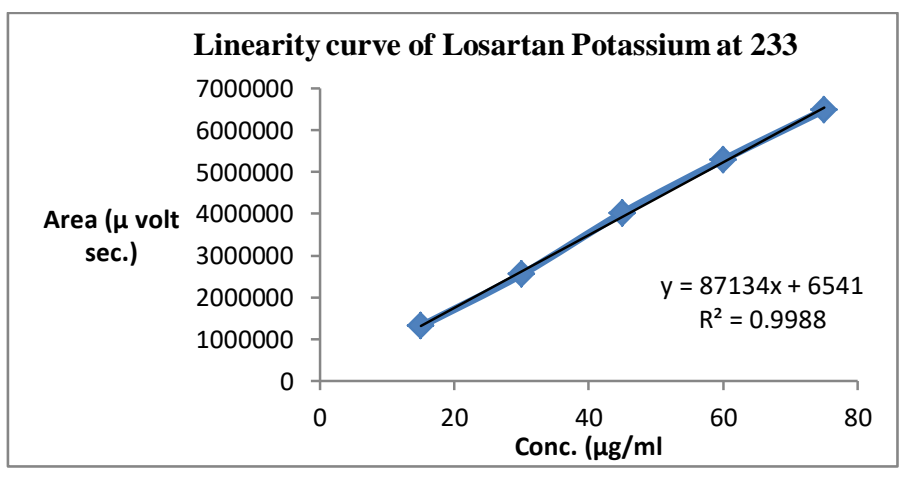

Figure 5: Linearity of Losartan potassium at $233 \mathrm{~nm}$ 


\subsubsection{Accuracy23-26}

Accuracy is the closeness of the test results obtained by the method to the true value. Accuracy may often express in terms of percent recovery of assay of known amount of analyte added. Recovery studies were carried out by addition of standard drug to the sample at 3 different levels of spiking i.e. $80 \%, 100 \%$ and $120 \%$ of the actual amount taking into consideration percentage purity of added bulk drug sample.Accuracy of Rosuvastatin calcium and Losartan potassium are shown in table $3 \& 4$ respectively.

Table 3: Accuracy of Rosuvastatin calcium at wavelength $233 \mathrm{~nm}$.

\begin{tabular}{|c|c|c|c|c|c|c|c|c|c|c|}
\hline \multirow{2}{*}{$\begin{array}{l}\text { Sr. } \\
\text { No. }\end{array}$} & \multirow{2}{*}{$\begin{array}{c}\begin{array}{c}\text { Amt. of } \\
\text { sample } \\
\text { Taken }\end{array} \\
(\mu \mathrm{g} / \mathrm{mL})\end{array}$} & \multirow{2}{*}{$\begin{array}{c}\begin{array}{c}\text { Amt. of } \\
\text { drug } \\
\text { added }\end{array} \\
(\mu \mathrm{g} / \mathrm{mL})\end{array}$} & \multirow{2}{*}{$\begin{array}{l}\text { Level of } \\
\text { addition } \\
(\%)\end{array}$} & \multicolumn{3}{|c|}{ Amount Recovered $\mu \mathrm{g} / \mathrm{mL}$} & \multirow[t]{2}{*}{ Mean } & \multirow[t]{2}{*}{ S.D } & \multirow[t]{2}{*}{$\%$ RSD } & \multirow{2}{*}{$\begin{array}{l}\text { \% Drug } \\
\text { recovery }\end{array}$} \\
\hline & & & & 1 & 2 & 3 & & & & \\
\hline 1 & 20 & 16 & $80 \%$ & 35.73 & 35.75 & 35.77 & 35.75 & 0.020 & 0.055 & 99.79 \\
\hline 2 & 20 & 20 & $100 \%$ & 39.82 & 39.76 & 39.95 & 39.84 & 0.097 & 0.243 & 99.87 \\
\hline 3 & 20 & 24 & $120 \%$ & 43.74 & 43.80 & 43.83 & 43.79 & 0.045 & 0.102 & 99.88 \\
\hline \multicolumn{9}{|c|}{ Mean of \% RSD } & 0.133 & \multirow[t]{2}{*}{99.42} \\
\hline \multicolumn{10}{|c|}{ Mean of \% Drug Recovery } & \\
\hline
\end{tabular}

Table 4: Accuracy of Losartan potassium at wavelength $233 \mathbf{n m}$.

\begin{tabular}{|c|c|c|c|c|c|c|c|c|c|c|}
\hline \multirow{2}{*}{$\begin{array}{l}\text { Sr. } \\
\text { No. }\end{array}$} & \multirow{2}{*}{$\begin{array}{c}\begin{array}{c}\text { Amt. of } \\
\text { sample } \\
\text { Taken }\end{array} \\
(\mu \mathrm{g} / \mathrm{mL})\end{array}$} & \multirow{2}{*}{$\begin{array}{c}\begin{array}{c}\text { Amt. of } \\
\text { drug } \\
\text { added }\end{array} \\
(\mu \mathrm{g} / \mathrm{mL})\end{array}$} & \multirow{2}{*}{$\begin{array}{l}\text { Level of } \\
\text { addition } \\
(\%)\end{array}$} & \multicolumn{3}{|c|}{ Amount Recovered $\mu \mathrm{g} / \mathrm{mL}$} & \multirow[t]{2}{*}{ Mean } & \multirow[t]{2}{*}{ S.D } & \multirow[t]{2}{*}{ \% RSD } & \multirow{2}{*}{$\begin{array}{l}\text { \% Drug } \\
\text { recovery }\end{array}$} \\
\hline & & & & 1 & 2 & 3 & & & & \\
\hline 1 & 30 & 24 & $80 \%$ & 53.70 & 53.85 & 53.74 & 53.76 & 0.077 & 0.143 & 99.55 \\
\hline 2 & 30 & 30 & $100 \%$ & 59.77 & 59.91 & 59.68 & 59.78 & 0.115 & 0.193 & 99.63 \\
\hline 3 & 30 & 36 & $120 \%$ & 65.89 & 65.80 & 65.75 & 65.81 & 0.070 & 0.107 & 99.71 \\
\hline \multicolumn{9}{|c|}{ Mean of \% RSD } & 0.147 & \multirow[t]{2}{*}{99.63} \\
\hline \multicolumn{10}{|c|}{ Mean of \% Drug Recovery } & \\
\hline
\end{tabular}

\subsubsection{Precision $27-29$}

The precision of an analytical method is the degree closeness of agreement between a series of measurements obtained from the multiple sampling of the same sample. Precision include repeatability, inter and intraday precision and reproducibility.

\subsubsection{Interday \& intraday precision}

Interday \& intraday precision of conc. $40,60,80 \mu \mathrm{g} / \mathrm{mL}$ was prepared and data was obtained for Rosuvastatin calcium. 3
Replicates were prepared for 3 days. Intraday and Inter day precision of Rosuvastatin calcium are shown in table $5 \& 7$ respectively.

Interday \& intraday precision of conc. $30,45,60 \mu \mathrm{g} / \mathrm{mL}$ was prepared and data was obtained for Losartan potassium. 3 replicates were prepared for 3 days. The absorbance for intraday were measured in 2 hours of interval table $6 \& 8$ respectively.

Table 5: Intraday precision of Rosuvastatin calcium at wavelength $233 \mathbf{n m}$.

\begin{tabular}{|c|c|c|c|}
\hline Conc. & $\mathbf{4 0} \boldsymbol{\mu g} / \mathbf{m L}$ & $\mathbf{6 0} \mathbf{\mu g} / \mathbf{m L}$ & $\mathbf{8 0} \boldsymbol{\mu g} / \mathbf{m L}$ \\
\hline \multirow{3}{*}{ Area ( $\boldsymbol{\mu}$ volt sec.) } & 3198754 & 4658794 & 6352489 \\
\cline { 2 - 4 } & 3196722 & 4657025 & 6352750 \\
\cline { 2 - 4 } & 3193688 & 4658411 & 6354875 \\
\hline Mean & 3196328 & 4658077 & 6353371 \\
\hline S D & 2449.46 & 930.68 & 0.020 \\
\hline
\end{tabular}


Table 6: Intraday precision of Losartan potassium at wavelength $233 \mathbf{n m}$.

\begin{tabular}{|c|c|c|c|}
\hline Conc. & $\mathbf{3 0} \boldsymbol{\mu g} / \mathbf{m L}$ & $\mathbf{4 5} \boldsymbol{\mu g} / \mathbf{m L}$ & $\mathbf{6 0} \boldsymbol{\mu g} / \mathbf{m L}$ \\
\hline \multirow{3}{*}{ Area ( $\boldsymbol{\mu}$ volt sec.) } & 2548455 & 4015878 & 5287945 \\
\cline { 2 - 4 } & 2546489 & 4015002 & 5286128 \\
\cline { 2 - 4 } & 2543441 & 4016855 & 5287369 \\
\hline Mean & 2546128 & 4015912 & 5287147 \\
\hline S D & 2426.38 & 926.95 & 928.56 \\
\hline \% RSD & 0.099 & 0.023 & 0.017 \\
\hline
\end{tabular}

Table 7: Interday precision of Rosuvastatin calcium at wavelength $233 \mathrm{~nm}$

\begin{tabular}{|c|c|c|c|}
\hline Conc. & $\mathbf{4 0} \boldsymbol{\mu g} / \mathbf{m L}$ & $\mathbf{6 0} \boldsymbol{\mu g} / \mathbf{m L}$ & $\mathbf{8 0} \boldsymbol{\mu g} / \mathbf{m L}$ \\
\hline \multirow{3}{*}{ Absorbance } & 3254821 & 4492973 & 6068210 \\
\cline { 2 - 4 } & 3256887 & 4494808 & 6063307 \\
\cline { 2 - 4 } & 3254096 & 4493926 & 6067274 \\
\hline Mean & 3255268 & 4493902 & 6066264 \\
\hline S D & 1448.19 & 917.72 & 2602.7 \\
\hline \% RSD & 0.044 & 0.020 & 0.042 \\
\hline
\end{tabular}

Table 8: Interday precision of Losartan potassium at wavelength $233 \mathbf{n m}$.

\begin{tabular}{|c|c|c|c|}
\hline Conc. & $\mathbf{3 0} \boldsymbol{\mu g} / \mathbf{m L}$ & $\mathbf{4 5} \boldsymbol{\mu g} / \mathbf{m L}$ & $\mathbf{6 0} \boldsymbol{\mu g} / \mathbf{m L}$ \\
\hline \multirow{3}{*}{ Area ( $\boldsymbol{\mu}$ volt sec.) } & 2739221 & 4472437 & 5848712 \\
\cline { 2 - 4 } & 2737392 & 4474480 & 5845732 \\
\cline { 2 - 4 } & 2738348 & 4475451 & 5846696 \\
\hline Mean & 2738320 & 4474123 & 5847047 \\
\hline S D & 914.81 & 1538.44 & 0.026 \\
\hline
\end{tabular}

\subsubsection{Repeatability 30}

For repeatability minimum of 6 determinants were prepared of $60 \mu \mathrm{g} / \mathrm{mL}$ conc. and the chromatogram responses were

Table 9: Repeatability of Rosuvastatin calcium at wavelength $233 \mathrm{~nm}$

\begin{tabular}{|l|l|}
\hline Sr. No & Area $(\boldsymbol{\mu}$ volt sec.) \\
\hline $\mathbf{1}$ & 3198754 \\
\hline $\mathbf{2}$ & 3196722 \\
\hline $\mathbf{3}$ & 3193688 \\
\hline $\mathbf{4}$ & 3196328 \\
\hline $\mathbf{5}$ & 3197856 \\
\hline $\mathbf{6}$ & 3192544 \\
\hline Mean & 3195982 \\
\hline S D & 2406.05 \\
\hline \%RSD & 0.075 \\
\hline
\end{tabular}

obtained by injecting one by one. The standard deviation \& relative standard deviation was calculated for each type of precision. Repeatability of Rosuvastatin calcium and Losartan potassium are shown in table $9 \& 10$ respectively.

Table 10: Repeatability of Losartan potassium at wavelength $233 \mathrm{~nm}$

\begin{tabular}{|l|l|}
\hline Sr. No & Area $(\boldsymbol{\mu}$ volt sec.) \\
\hline $\mathbf{1}$ & 2548455 \\
\hline $\mathbf{2}$ & 2546489 \\
\hline $\mathbf{3}$ & 2543441 \\
\hline $\mathbf{4}$ & 2546128 \\
\hline $\mathbf{5}$ & 2545658 \\
\hline $\mathbf{6}$ & 2546322 \\
\hline Mean & 25466082 \\
\hline S D & 1613.14 \\
\hline \%RSD & 0.063 \\
\hline
\end{tabular}




\section{Kumar et al}

\subsubsection{Limit of detection (LOD) ${ }^{31-32}$}

LOD is the lowest amount of analyte in a sample which can be detected but not necessarily quantitated as an exact value. LOD was calculated by the standard deviation of the response and the slope.

$$
L O D=\frac{3.3 \times \sigma}{S}
$$

Where, $\sigma=$ the standard deviation of the response

$\mathrm{S}=$ the slope of the calibration curve

The slope and standard deviations were calculated from the linearity curve obtained for conc. ranges of $20-100 \mu \mathrm{g} / \mathrm{mL}$ for Rosuvastatin calcium and 15-75 $\mu \mathrm{g} / \mathrm{mL}$ for Losartan potassium.

\subsubsection{Limit of quantitation (LOQ) ${ }^{33-35}$}

It is the lowest amount of analyte in a sample which can be quantitatively determined with suitable precision and
Journal of Drug Delivery \& Therapeutics. 2020; 10(5-s):76-84 accuracy. LOQ was calculated by the standard deviation of the response and the slope. The data was obtained from linearity curve and the LOQ was calculated.

$$
L O Q=\frac{10 \times \sigma}{S}
$$

Where, $\sigma=$ the standard deviation of the response $\mathrm{S}=$ the slope of the calibration curve

The slope and standard deviations were calculated from the linearity curve obtained for conc. ranges of $20-100 \mu \mathrm{g} / \mathrm{mL}$ for Rosuvastatin calcium and $15-75 \mu \mathrm{g} / \mathrm{mL}$ for Losartan potassium.

LOD \& LOQ for Rosuvastatin calcium and Losartan potassium are shown in table $11 \& 12$ respectively.

Table 11: LOD \& LOQ of Rosuvastatin calcium at $233 \mathrm{~nm}$ wavelength

\begin{tabular}{|c|c|c|c|}
\hline Conc. & Abs. & Amount Recovered $\boldsymbol{\mu g} / \mathbf{m L}$ & \% Drug recovery \\
\hline 20 & 1548754 & 20.40883781 & 102.0442 \\
\hline 40 & 3198757 & 40.64533458 & 101.6133 \\
\hline 60 & 4658794 & 58.55198931 & 97.58665 \\
\hline 80 & 6352489 & 79.32434753 & 99.15543 \\
\hline 100 & 8125481 & 101.0692455 & 101.0692 \\
\hline Mean & & 100.2938 \\
\hline SD & 1.872892 \\
\hline SE of Intercept & 228401.4 \\
\hline SD Of Intercept & 9.244071 \\
\hline
\end{tabular}

Table 12 : LOD \& LOQ of Losartan potassium at $233 \mathrm{~nm}$ wavelength

\begin{tabular}{|c|c|c|c|}
\hline Conc. & Abs. & Amount Recovered $\boldsymbol{\mu g} / \mathbf{m L}$ & \% Drug recovery \\
\hline 15 & 1310158 & 14.96106 & 99.7404 \\
\hline 30 & 2548455 & 29.17247 & 102.2521 \\
\hline 45 & 4015878 & 46.01346 & 101.0207 \\
\hline 60 & 5287945 & 60.61244 & 98.98844 \\
\hline 75 & 6475485 & 74.24133 & 99.84865 \\
\hline \multicolumn{3}{|c|}{ Mean } & 1.916969 \\
\hline SE of Intercept & 86118.71 \\
\hline SD Of Intercept & 192567.3 \\
\hline LOD & 7.293043 \\
\hline
\end{tabular}




\subsubsection{Robustness $36-39$}

Robustness is a measure of its capacity to remain unaffected by small, but deliberate variations in method parameter. For HPLC robustness was carried out by changing wavelength and flow rate. Robustness of a method was done by change in wavelength, or change in flow rate of a mobile phase. Injection of $20 \mu \mathrm{g} / \mathrm{mL}$ was prepared from the stock solution and the recorded. Robustness data for Rosuvastatin calcium and Losartan potassium are shown in Table 13 and 14.

\section{Change in Wavelength}

Table 13: Robustness of Rosuvastatin calcium and Losartan potassium at wavelength $233 \pm 2 \mathrm{~nm}$.

\begin{tabular}{|c|c|c|c|}
\hline Wavelength & Difference & $\begin{array}{l}\text { Rosuvastatin calcium } \\
\text { (min.) }\end{array}$ & $\begin{array}{l}\text { Losartan potassium } \\
\text { (min.) }\end{array}$ \\
\hline $\mathbf{2 3 1}$ & -2 & 3.465 & 4.464 \\
\hline $\mathbf{2 3 3}$ & 0 & 3.550 & 4.358 \\
\hline $\mathbf{2 3 5}$ & +2 & 3.598 & 4.129 \\
\hline
\end{tabular}

Table 14: Robustness of Rosuvastatin calcium and Losartan potassium at wavelength $233 \mathrm{~nm}$ by changing the flow rate.

\begin{tabular}{|c|c|c|c|}
\hline Flow rate (ml/min.) & Difference & $\begin{array}{l}\text { Rosuvastatin calcium } \\
\text { (min.) }\end{array}$ & $\begin{array}{l}\text { Losartan potassium } \\
\text { (min.) }\end{array}$ \\
\hline $\mathbf{0 . 9}$ & 3.466 & 4.421 & 3.662 \\
\hline $\mathbf{1}$ & 3.550 & 4.358 & 3.550 \\
\hline $\mathbf{1 . 1}$ & 3.602 & 4.375 & 3.453 \\
\hline
\end{tabular}

The overall validation parameter data are shown in Table 15. It complied with ICH guidelines.

Table 15: Summary of validation parameters of RP-HPLC at $233 \mathrm{~nm}$ wavelength.

\begin{tabular}{|c|c|c|}
\hline Parameter & Rosuvastatin calcium & Losartan potassium \\
\hline & & $15-75$ \\
\hline Linear range in $(\mu \mathrm{g} / \mathrm{mL})$ & $20-100$ & 0.9988 \\
\hline Regression coefficient $\left(\mathrm{R}^{2}\right)$ & 0.9989 & \% RSD NMT 2 \\
\hline \%Accuracy & 99.42 & \%RSD NMT 2 \\
\hline Repeatability (n=6) & \%RSD NMT 2 & 7.293043 \\
\hline Precision & \%RSD NMT 2 & 22.10013 \\
\hline Interday precision & & 9.244071 \\
\hline LOD & 28.01233 & \\
\hline
\end{tabular}

\section{DISCUSSION}

\section{Reversed phase-high performance liquid chromatography (RP-HPLC)}

the method was developed for the simultaneous estimation of Rosuvastatin calcium and Losartan potassium using Reverse Phase - High Performance Liquid Chromatography. All the parameters were validated according to the ICH guidelines and meet all the limits. Various trials were taken for the Rosuvastatin calcium and Losartan potassium at certain conditions. The linearity for method was obtained at $233 \mathrm{~nm}$ for Rosuvastatin calcium and Losartan potassium. The $\mathrm{R}^{2}$ values were found 0.9988 and 0.9989 for Rosuvastatin calcium and Losartan potassium respectively. The $\mathrm{R}^{2}$ value was within the limits of $0.995-0.999$, and has good linearity. For accuracy of method the \% drug recovery was calculated for both drugs at wavelength $233 \mathrm{~nm}$ at conc. of $80,100,120 \%$ and average recovery was found $99.42 \%$ for Rosuvastatin calcium and $99.63 \%$ for Losartan potassium. As the \% drug recovery should be considered within limits i.e. $100 \pm 2 \%$. Interday precision was calculated by preparing dilutions of 40,60 and $80 \mu \mathrm{g} / \mathrm{ml}$ conc. for Rosuvastatin calcium and 30,45, $60 \mu \mathrm{g} / \mathrm{ml}$ concentrations for Losartan potassium \& responses were obtained at wavelength $233 \mathrm{~nm}$. Interday precision for Rosuvastatin calcium for $1^{\text {st }}$ day the \%RSD was found $0.079,0.019$, and 0.020 at wavelength 233 . For $2^{\text {nd }}$ day the $\%$ RSD was found $0.044,0.020$, and 0.042 at wavelength $233 \mathrm{~nm}$. For $3^{\text {rd }}$ day the $\%$ RSD was found $0.049,0.039$, and 0.036 at wavelength $233 \mathrm{~nm}$. The concentration 40,60 and $80 \mu \mathrm{g} / \mathrm{ml}$ was used in triplicate at different days. Interday precision for Losartan 


\section{Kumar et al}

potassium for 1 st day the $\%$ RSD was found $0.033,0.034$, and 0.026 at wavelength 233 . For $2^{\text {nd }}$ day the $\%$ RSD was found $0.049,0.036$, and 0.036 at wavelength $233 \mathrm{~nm}$. For $3^{\text {rd }}$ day the $\%$ RSD was found $0.063,0.035$, and 0.037 at wavelength $233 \mathrm{~nm}$. The concentration 30,45, $60 \mu \mathrm{g} / \mathrm{ml}$ was used in triplicate at different days. For repeatability the \% RSD was found $0.075 \%$ at wavelength $233 \mathrm{~nm}$ for Rosuvastatin calcium. For Losartan potassium the \% RSD was found 0.063 $\%$ at wavelength 233 i.e. within the limit. It shows that the method qualifies the criteria of repeatability. LOD \& LOQ was calculated from the linearity curve at wavelength 233 and the LOD was found $9.2440 \mu \mathrm{g} / \mathrm{ml}$ and LOQ was found $28.0123 \mu \mathrm{g} / \mathrm{ml}$ for Rosuvastatin calcium. For Losartan potassium LOD was found $7.2930 \mu \mathrm{g} / \mathrm{ml}$ and LOQ was found $22.1001 \mu \mathrm{g} / \mathrm{ml}$ at wavelength $233 \mathrm{~nm}$. Robustness of Rosuvastatin calcium and Losartan potassium at $233 \mathrm{~nm}$

The method was found robust as there was change in wavelength to $\pm 2 \mathrm{~mL}$ and change in flow rate of \pm 0.1 $\mathrm{mL} / \mathrm{min}$.

\section{CONCLUSION:}

RP-HPLC method was developed for Rosuvastatin calcium and Losartan potassium. The chromatographic condition for optimized method was found to consisting of Column C-18 (Shim-pack) $250 \times 4.6 \mathrm{~mm}$, particle size $5 \mu \mathrm{m}$, mobile phase acetonitrile, methanol and water $\mathrm{pH} 3$ (orthophosphoric acid) in the ratio 20:25:55. The retention time were found to be 3.55 and $4.64 \mathrm{~min}$ and average percentage recovery 99.42\% and $99.63 \%$ for Rosuvastatin calcium and Losartan potassium respectively. The proposed methods were found to comply with ICH guidelines. These methods can be further employed in future for the routine determination of Rosuvastatin calcium and Losartan potassium in bulk drug.

\section{REFERENCES:}

1. Anne Waugh \& Allison Grant Ross and Wilson Anatomy and Physiology in Health and Illness International Edition, 13th Edition: 07/2018

2. https://www.nhs.uk/conditions/cardiovasculardisease

3. https://www.who.int/news-room/factsheets/detail/cardiovascular-diseases-(cvds)

4. https://www.heart.org/en/health-topics/consumerhealthcare/what-is-cardiovascular-disease

5. https://www.mayoclinic.org/diseases-conditions/heartdisease/symptoms-causes/syc-20353118

6. Donald L, Pavia MG, Lampman SGK, JamesR. Introduction to Spectroscopy Department of Chemistry Western Washington University Bellingham, Washington. 2001; 3.

7. Snyder Lloyd R, Kirkland Joseph J, Glajch Joseph J, Practical HPLC Method Development, 2nd Edition

8. https://www.intechopen.com/books/calibration-andvalidation-of-analytical-methods-a-sampling-of-currentapproaches/validation-of-analytical-methods.

9. https://www.drugbank.ca/drugs/DB01098

10. https://www.drugbank.ca/unearth/q?utf8= $\checkmark$ \&searcher=drugs\&query=losartan

11. Yadav J, Sharma A. A Review on Analytical Methods for Estimation of Aspirin, Clopidogrel Bisulphate and Rosuvastatin Calcium in Pharmaceutical Dosage Form. In Pharmaceutical Dosage Form; PharmaTutor. 2017; 5(9):35-46

12. Telrandhe R. Development and Validation of RP-HPLC method for simultaneous determination of Rosuvastatin and Clopidogrel in Tablet dosage form. 2017; 1-15.

13. Vijayalakshmi R, Kalyani P, Sandya P, Rao PC, Dhanaraju MD. RP-HPLC Method for the Simultaneous Estimation of Perindopril and Losartan in Pure Form and Tablet Formulations. International Journal of Pharmaceutical Sciences and Drug Research. 2014; 6(1): 75-77.

14. Chaitanya KK, Sankar DG, Samson D. Israel. RP-HPLC Method for the Simultaneous Estimation of Amlodipine and Losartan in Binary Mixture. Department of Pharmaceutical Analysis and Quality Assurance A.U.College of Pharmaceutical sciences,
Journal of Drug Delivery \& Therapeutics. 2020; 10(5-s):76-84

Andhra University, Visakhapatnam-530 003, A.P, India. 2012; 4(3):1144-1152.

15. Anandkumar R, Tengli G, Neeraj BMS. Simultaneous estimation of hydrochlorothiazide, amlodipine, and losartan in tablet dosage form by RP-HPLC Department of Parmaceutical Chemistry, JSS College of Pharmacy, JSS University, S.S. Nagar, Mysore 570015, India. 2013; 4(1): 3338.

16. Mhaske RA, Sahasrabudhe S, Mhaske AA. RP-HPLC Method for Simultataneous Determination of Irbesartan, Losartan, Hydrochlorothiazide and Chlorthalidone-Application to Commercially Available Drug Products, IJPSR. 2019; 11161123.

17. Bhatia NM, Sachin B, Gurav, Swapnil D, Jadhav, Manish S. Bhatia Bharati Vidyapeeth College of Pharmacy, Kolhapur, India Journal of Liquid Chromatography \& Related Technologies. 2012; 35(3): 428-443.

18. Oza CK, Prajapati JP, Vyas AJ. Mehta Institute of pharmacy, Nirma University of Science \& Technology, Ahmedabad. India. Zydus Research Center, Ahmedabad. India. Bkmody Govt. Pharmacy College Rajkot, India. 2011; 2(1):709-711.

19. Arif HM, Ahsanul HM, Irin D, Hamidul KNM, Hossain KM. Development and Validation of RP-HPLC Method for the Simultaneous Estimation of Hydrochlorothiazide and Losartan Potassium in Tablet Dosage Form, Dhaka Univ. J. Pharm. Sci. 2011; 10(1):35-42.

20. Sreekanth N, Shivshanker K, Shanmuga PP, Roosewelt C,Rao SG, Gunasekaran V. Department of Pharmaceutical Analysis, Vel's College of Pharmacy Old Pallavaram, Chennai-600 117, India. 2009; 10-15.

21. Dubey R, Bhusari VK, Dhaneshwar SR. Validated RP-HPLC Method for Simultaneous Quantitation of Losartan Potassium and Metolazone in Bulk Drug and Formulation. Department of Pharmaceutical Chemistry, Bharati Vidyapeeth University, Poona College of Pharmacy, Pune, Maharashtra, 411038, India. 2011; 79:545- 554.

22. Malavika. LV, Uttam PD, Satish G, Kiran VP. Mangaonka Simultaneous estimation of aspirin, atenolol, atorvastatin and losartan from their combination dosage form by RP-HPLC. 2012; 35(3): 428-443.

23. Patel B, Alpa J, Solanki H, Parmar, Parmar V, Kumari A. Validated RP-HPLC Method for Simultaneous Quantitation of Losartan Potassium and Metolazone in Bulk Drug and Formulation. Department of Pharmaceutical Science, Sardar Patel University, Vallabh Vidyanagar-388120, Gujarat, India. 2011; 79:545-554.

24. Chaudhary AB, Patel RK, Chaudhary S. Determination of Losartan Potassium and Perindopril Erbumine in Tablet Formulations by Reversed-Phase HPLC, IJCRGG ISSN: 09744290. 2010; 2(2):1141-1146.

25. Patil PR, Rakesh, Sachin U. Prof Dhabale, P. N. Prof. K. B. Burade, RP- HPLC Method for Simultaneous Estimation of Losartan potassium and Amlodipine besylate in Tablet Formulation International Journal of ChemTech Research CODEN(USA): IJCRGG. 2009; 1(3): 464-469.

26. Vijayalakshmi R, Kalyani P, SandyaP, Dhanaraju MD. RP-HPLC Method for the Simultaneous Estimation of Atrovastatin and Losartan in Pure and Tablet Formulations. IJRPC 2009; 2(3):2231-2781.

27. Thomas AB, Chavan UB, Nanda RK, Kotha palli LP. Simultaneous Spectrophotometric Estimation of Hydrochlorothiazide, Atenolol and Losartan Potassium in Tablet Dosage Form. Journal of Pharmaceutical Research. 2009; 8(3):139-141.

28. Jayaseelan S, Rajasekar M, Ganesh S, Sekar V, Perumal P. RPHPLC method development and validation for simultaneous estimation of Losartan Potassium, Amlodipine Besilate and Hydrochlorthiazide in tablet dosage form. Department of Pharmaceutical Analysis. 2010; 2 (3):31-36.

29. Chiu, A.T., McCall, D.E., Price, W.A., Nonpeptide angiotensin Il receptor antagonists. VII. Cellular and biochemical pharmacology of DuP 753, an orally active antihypertensive agent. J. Pharmacol. Exp. Ther. 1990; 252:711-718.

30. Prabhakar, A.H., Giridhar, R., A rapid colorimetric method for the determination of Losartan potassium in bulk and in synthetic mixture for solid dosage form, J. Pharm. Biomed. Anal. . 2002; 27(6):861- 866.

31. Saner T, "Determination of Rosuvastatin calcium in its bulk drug and pharmaceutical preparations by high-performance 
thin-layer chromatography." J. planar chromatography, 2005; 18:194-198.

32. Sharma MC, Kohli DV, Sharma AD, "A validated HPTLC method for determination of simultaneous estimation Rosuvastatin Calcium and Ezetimibe in pharmaceutical solid dosage form." Arch. Applied Sci. Res. 2010; 2(1):1-7.

33. ICH guidelines, validation of analytical procedure: Q2A, I.C.H. Harmonized Tripartite Guidelines, 1996.

34. Kavitha, J. and Muralidharan, S. Development and validation of new method for atenolol, hydrochlorothiazide and losartan potassium by RP-HPLC: It's Application to routine quality control analysis. Int. J. Chem. Tech. Res. 2010; 2:880-884 27

35. Priyanka, R.P., Sachin U.R., Dhabale, P.N. and Burade, K.B. RP HPLC method for simultaneous estimation of losartan potassium and amlodipine besylate in tablet formulation. Int. J. Chem. Tech. Res. 2009; 1:464-469.

36. Brunetto, M.R.; Contrerasa, Y.; Clavijo, S.; Torresa, D.; Delgadoa, T.; Delgadoa, Y.; Ovalles, F.; Ayala, C.; Gallignania, M.; Gallignania, J. M.; Martin, V. C. Determination of Losartan,
Telmisartan, and Valsartan by Direct Injection of Human Urine into a Column-Switching Liquid Chromatographic System with Fluorescence Detection. J. Pharm. Biomed. Anal. 2009; 50:194-199

37. Pournima P, Vaishali B. Spectrophotometric method for simultaneous determination of olmesartan medoxomil and amlodipine besylate from tablet dosage form. Int J Curr Pharm Res. 2011; 3(2):74e79.

38. Williams RC, Alasandro MS. Comparison of liquid chromatography, capillary electrophoresis and super-critical fluid chromatography in the determination of losartan potassium drug substance in Cozaar tablets. J Pharm Biomed Anal. 1996; 14(11):1539e1546.

39. Furtek CI and Lo MW. Simultaneous determination of a novel angiostensin II receptor blocking agent, Losartan and its metabolite in human plasma and urine by high performance liquid chromatography. J Chroma Biomed Appn. 1992; 573:295-301. 